\title{
Re-Assessing the Cultivation Theory in Relation to Critics: Research Made Through Positive and Negative Patterned Questionnaires
}

\author{
Prof. Dr. Ömer Özer \\ Faculty of Communication Sciences \\ Department of Journalism, Anadolu University
}

Doi:10.5901/ajis.2013.v2n8p757

\section{Abstract}

In terms of cultivation analysis, cultivation concept explains the contribution of television watching to global perception and social reality conceptualization of the viewers (Morgan, 1984: 500). In the first cultivation study, the theory was defined as the random and unintentional learning, and unconscious gaining of demographic realities of television world by the viewers (Gerbner and Gross, 1976:170). Cultivation analysis examines the relationship between the most recurrent and expansive images and ideologies in television content with the social reality conceptualization of the viewers (Gerbner et al., 1980; Morgan and Signorielli, 1990). The component focuses on the overall results of growing up and living with television. The research of the article based on the conceptualized criticism called participant bias in the cultivation studies carried out by George Gerbner and his friends has been conducted at Ankara Kurtuluş High School. In the field research, in parallel to the purpose, negative patterned questions reflecting the television world used by Gerbner and his friends, and the positive variations of these are used; in the analysis whether the two groups with the same indicators gave the same answers to each question has been studied. The results seem to be confirming Gerbner and his friends.

\section{Introduction}

The research of this article is based on the conceptualized criticism called participant bias in the cultivation studies carried out by George Gerbner et al. and has been conducted at Ankara Kurtulus High School. In the field research, in parallel to the purpose, negative patterned questions reflecting the television world used by Gerbner et al., and the positive variations of these are used; in the analysis whether the two groups with the same indicators gave the same answers to each question has been studied.

\section{Cultural Indicators Project}

With the surveys conducted for Cultural Indicators Project, Gerbner attempted to put forth the proof regarding his belief that mass communication media are an arm of established industrial order. The Project, also referred to as Cultivation theory, involves a three-pronged research strategy. The first strategy known as the institutional process analysis investigates how the flow of media messages is produced and managed, how decisions are made, and how media organisations function. (Gerbner, 1973)

The second prong, message system analysis, is important as it addresses the questions establishing cultivation analysis. The questions used in cultivation analysis reflect from content profiles that have settled in television message system presented to vast viewer groups throughout a long period of time since babyhood (Gerbner, 1990: 253). Any kind of misanalysis here would simply lead to false results in field research.

Message system analysis identifies how communities are formed through mass communication process, what the most shared dispositions and propositions are (Morgan, 1995: 107). To Gerbner, any message is a socially and historically determined expression of concrete physical and social relationships. Messages imply propositions, assumptions and points of view that are understandable only in terms of the social relationships and contexts in which they are produced. Yet they also reconstitute those relationships and contexts. Messages thus sustain the structures and practices that produce them (Morgan, 1995: 104).

There are many critical discrepancies between the world and the world as portrayed on television (Gerbner et al., 1994: 25). Findings from systematic analyses of television's message systems manifest those discrepancies. Message system analysis identifies the most recurrent, stable, and overarching patterns of television content. These are the consistent images, portrayals, and values that cut across most types of programs and are virtually inescapable for heavy 
viewers. They are the aggregate messages embedded in television as a system rather than in specific programs, types, channels, or genres (Gerbner et al., 1986).

The third prong, cultivation analysis, is used to define the television's contribution to viewers' social reality conceptualisation (Morgan, 1984: 500). In the first cultivation research the fact that viewers unconsciously obtain demographic realities of the television world is defined as random and indeliberate learning (Gerbner and Gross, 1976: 170). Cultivation analysis examines the relationship between viewers' social reality conceptions and most repetitive and long-range images and ideologies (Gerbner et al., 1980a; Morgan and Signorielli, 1990). The prong focuses on overall results of growing up and living with television.

Cultivation analysis was first conducted in early 1970s, with a field research targeting adults (Gerbner and Gross, 1976). In its simplest form, cultivation analysis suggests that heavy viewers of television perceive the most common and recurrent television world messages as an accurate depiction of the real world. It compares the answers of light viewers and heavy viewers using demographic variables as controls (Morgan and Signorielli, 1990: 16).

In this part, it is necessary to emphasise a point that is also important in terms of the research. Gerbner et al. postulate that exposure to violence on television leads to a "mean world" perception.

\section{Research on the Cultivation Role of Television in Turkey}

Some researches defining the world of television based on all or some of the components of Cultural Indicators Project, developed by George Gerbner in the USA, focusing on the (cultivation) role of television on the social reality conceptualization and the world perception of people have also been conducted in Turkey. The first of these was the subject of the doctoral dissertation by Veysel Batmaz (1986) in the early mid-1980s. In the study, only a cultivation analysis was made, and the role of television was seen in the commercials, but not in the violent acts. The study not only conducted a cultivation analysis but it also highlighted some different aspects. In that sense, it is necessary to identify it as a model experiment.

Around the time when Batmaz completed his dissertation, Konca Yumlu substantially made use of Gerbner's project in her doctoral dissertation and revealed the television content (Yumlu, 1987).

In another research carried out in the early 1990s and published in 1995, both message system and cultivation analyses were used and the role of television was determined (Batmaz and Aksoy, 1995). This research has a unique importance as it centres around Turkey, and other than using message system and cultivation analysis, it also reveals to what extent television is used in Turkey (as part of daily life).

In 2000s, in a study that has used all three prongs, it is determined that television has a role of cultivation on university students (Özer, 2004). In this research, for the first time in Turkey, institutional process, message system, and cultivation analyses were used together and the role of cultivated messages of televised world on people was questioned. It was concluded that television does have such a role, and also institutional process analyses, which proved that the cultivated messages of television were not randomly prepared, were also made.

Following this research, which revealed the cultivational role of television on students, in another research with a different group of university students, it was concluded that television does not have a cultivational role (Özer, 2005c). In another research examining whether violence comes from immediate surroundings or television, it was concluded that cultivation relates to television (Özer, 2005). In a research examining the cultivational role of television on employees also produced proof to assert cultivation (Özer, 2005a). Another research on university graduate employees also displayed similar results (Özer, 2005b). In a recent doctoral dissertation only cultivation analysis was used (Taylan, 2011).

\section{Criticisms of the Studies of Gerbner and His Friends}

Many researchers criticised the studies of Gerbner et al. in terms of Message System and Cultivation Analyses from the starting point until mid-1980s. A summary of these criticisms was presented by Rubin et al. (1988). In 1990s, Potter (1991; 1991a; 1991b) also made some criticisms. In Turkey, there has not been a substantial criticism of Gerbner's ideas and his project (Erdoğan: 1998). Under this title some of the criticisms are reminded:

Newcomb criticised them for using an arbitrary violence conceptualisation (transferred by Shanahan and Morgan, 1999). According to Morgan and Shanahan (1997: 10), who are among the foremost representatives of Cultivation research, although Newcombs' approach is correct, it does not contradict with the proposals of Cultivation Analysis.

Criticisms towards the definition of violence by Gerbner et al. are directed to the fact that images containing natural disasters and such are also considered part of violence. Furthermore, Gerbner et al. received criticisms for founding their 
definition of violence on a "narrow sense confined with physical actions" (Çelik, 2000:12).

One of the other criticisms of Cultivation Analysis can be called as other variables problem. The most known of these came from Hirsch. Between Gerbner et al. and Hirsch harsh disputes took place in the form of claim (accusation)response (accusation) ((Hirsch, 1980, 1981; Gerbner vd., 1980, 1980a, 1982). In response to Hughes and others' criticisms, Gerbner and his associates pioneered the factors of "mainstreaming".

Cultivation Analysis also received criticism in terms of individual differences from Gunter and Wober. On the other hand, the media-effect researches on its contribution to socialisation remain distant to the hypothesis of Cultivation Analysis that "there is a correlation between television viewing and negative socialisation, and individual perceptions". These criticisms were made by Robert and Maccoby (transferred by Rubin et al., 1998).

Cultivation Analysis of Gebner et al. was also criticised for its hypothesis that admits the relationship between television viewing and cultivation could only be fake or explained by other factors. This is called fake relationship. This criticism comes from Doob and Mcdonald (1979).

Gebner et al. suggest that television is unique in its presentation symbolic messages about the society. This view was criticised by Hawkins and Pingree (1981: 297): Cultivation can be associated with some television content, but not with some others and total viewing. Besides, Slater and Elliot (transferred by Rubin et al., 1988) criticise cultivation theory for not proving that viewers accept the television reality. Some researchers reminding the criticism made by Lenski and Luggett that claims Srole's alienation scale is sensitive to 'I agree' response set criticised Gerbner et al. who used the scale (transferred by Rubin et al., 1988: 110).

Following information can be related in terms of the criticism that forms the basis of the study: Hirsch and some other researchers argue viewer bias could foster cultivation. That's why; negatively constructed survey questions are more likely to produce a result more than the positive ones. Hughes pointed out the same issue. Wober discovered different cultivation questions lead to different results. An English case research demonstrated that questions on interpersonal distrust and interpersonal trust problems did not give the same results. As a result of a research they conducted on $2^{\text {nd }}$ grade Australian primary schoolchildren, Hawkins and Pingree found that only a survey with negative questions is related to television viewing (Transferred by Rubin et al., 1988: 110).

\section{Methodology}

The field research was carried out at Kurtuluş High School in Ankara. For each survey group (negative and positive) 90 students took part. 45 of them were girls, 45 were boys. 6 questions were used for the field research. The survey with negative questions was given to one group; the other one with the positive varieties was given to the other group. Here are the questions used in the field research:

1. "Generally speaking, we live in a dangerous/safe world."

2. "Generally speaking, people are unreliable/reliable."

3. "Generally speaking, many people behave dishonestly/honestly and try/do not try to take advantage of you when they find the opportunity."

4. "Generally speaking, people usually do not help/help others; they act selfishly/unselfishly."

5. "Generally speaking, walking out alone at night is dangerous/safe.

6. "Generally speaking, most people do not feel safe/feel safe."

SPSS has been used to evaluate the data. The medians of questions were found in accordance with the aim of the study. Median is the central tendency measure. In such kind of researches, of the tree measures of central tendency, which are mean, medium and mode, medium is the main determiner along with mean. Mode and average also give an idea. However, median gives where a particular group stands: 1, 2, 3, 4, or 5. Mode shows which category is the most chosen one.

In terms of evaluation, each question is expected to give the same median with both negative and positive questions. The same medians have falsified the criticisms; different medians have justified the criticisms.

\section{Findings}

In order to understand the results, a point should be emphasized. In two tables there are 6 categories. In each category, the words interrelate with each other. For instance, in Table 1 the word "safe" represents the positive variation of the question; and in Table 2 the same word represents the negative variation. Expectedly, if the median is 1 in one of the tables, in the other one it should be 5. For 2, 4 is expected; for 3, again 3 is expected. 
Table 1: Medians of Positive Variation Questions

\begin{tabular}{|c|c|c|c|c|c|c|}
\hline & Safe & Reliable & People & Honest & Alone & Feel Safe \\
\hline Number Valid & 90 & 90 & 90 & 90 & 90 & 90 \\
Median & 3 & 4 & 4 & 4 & 4 & 3 \\
\hline
\end{tabular}

Table 2: Medians of Negative Variation Questions

\begin{tabular}{|c|c|c|c|c|c|c|}
\hline & Safe & Reliable & People & Honest & Alone & Feel Safe \\
\hline Number Valid & 90 & 90 & 89 & 89 & 89 & 90 \\
Median & 2 & 2 & 2 & 2 & 2 & 2 \\
\hline
\end{tabular}

The medians of the first and sixth questions came out differently. The medians of the second, third, fourth and fifth questions corresponded to each other. As a result, it is seen that the responses for positive and negative questions are the same in four questions whereas the responses for two questions are different (Table 1 and 2). Therefore, in terms of 6 questions there is a $67 \%$ of correspondence. It is, thus, possible to suggest that cultivation tests are valid for $67 \%$. Nevertheless, this could be valid only for a cultivation research to be conducted at Kurtuluş High School. A more acceptable evaluation could be explained as follows: for a cultivation research to be conducted at Kurtuluş High School, using questions 2, 3, 4, and 5 would eliminate the participant bias criticism.

\section{Conclusion}

In this study, the criticism conceptualised as participant bias and directed at Cultivation researches developed by Gerbner et al. has been examined. For the validity of the abovementioned criticism, the results of the research with negative and positive-patterned questions are analysed. The research does not generalise.

The results did not completely verify the criticism. The medians for two questions did not match. 4 medians out of 6 matched with each other. These results could suggest that participant bias is relative.

Two suggestions can be made in the light of this research: In Turkey, the number of Cultivation researches has increased despite the limited number researchers. The number, however, is still not adequate especially when the fact that Cultivation researches should be carried out constantly is considered. Furthermore, the researches could also relate to the other criticisms of Cultivation Analysis. Finally, conducting cultivation researches regarding the new media would be quite beneficial.

\section{References}

Batmaz, Veysel (1986). Bir Kitle İletişim Aracı Olarak Televizyonun Siyasal ve Toplumsal Etkileri: Ampirik Bir Model Denemesi, Ankara Üniversitesi Sosyal Bilimler Enstitüsü: Doktora Tezi.

Batmaz, Veysel ve Asu Aksoy (1995). Türkiye'de Televizyon ve Aile, T.C. Başbakanlık Aile Araştırma Kurumu.

Çelik, Nur Betül (2000). "Giriş: Televizyon, Kadın ve Şiddet", içinde Televizyon Kadın ve Şiddet, Der. Nur Betül Çelik, KIV Yayınları.

Doob, N. Anthony ve Glenn E. Macdonald (1979). "Television Viewing and Fear of Victimization: Is the Relationship Causal?", Journal of Personality and Social Psychology, 37(2): 170-9.

Erdoğan, İrfan (1998). "Gerbner'in Ekme Tezi ve Anlattığı Öyküler Üzerine Bir Değerlendirme”, Kültür ve İletişim, 1(2): 149-80.

Gerbner, George (1973). "Cultural Indicators: The Third Voice", içinde Communication Technology and Social Policy, Ed. George Gerbner vd., John Wiley and Sons: 555-73.

Gerbner, George (1990). "Epilogue: Advancing on the Path of Righteouness (Maybe)", içinde Cultivation Analysis: New Directions in Media Effects Research, Ed. Nancy Signorielli ve Michael Morgan, Sage Publication: 249-62.

Gerbner, George ve Lary Gross (1976). Living with Television: The Violence Profile", Journal of Communication, 26(2): 173-99.

Gerbner, George ve Nancy Signorielli (1979). Women and Minorities in Television Drama 1969-1978, University of Pennsylvania The Annenberg School of Communications Philadelphia, Pennsylvania.

Gerbner, George vd. (1980). "Aging with Television: Image on Television Drama and Conceptions of Social Reality", Journal of Communication, 30(1): 37-47.

Gerbner, George vd. (1980a). "The Mainstreaming of America: Violence Profile No:11", Journal of Communication, 30(3): 10-29.

Gerbner, George vd. (1982). "Charting the Mainstream: Television's Contributions to Political Orientations", Journal of Communication, 32(2): 100-27.

Gerbner, George vd. (1986). "Living with Television: The Dynamics of the Cultivation Process", içinde Perspectives on Media Effects, Ed. Jennings Bryant ve Dolf Zillmann, Lawrence Erlbaum: 17-40. 
Gerbner, George vd. (1994). "Growing up with Television: The Cultivation Perspective", içinde Media Effects: Advances in Theory and Research, Ed. Jennings Bryant ve Dolf Zillmann, Lawrence Erlbaum: 17-41.

Hawkins, P. Robert ve Suzanne Pingree (1981). "Uniform Content and Habitual Viewing: Unnecessary Assumption in Social Reality Effect", Human Communication Research, 7: 291-301.

Hirsch, M. Paul (1980). "The Scary World of the Nonviewer and Other Anomalies", Communication Research, 7(4): 403-56.

Hirsch, M. Paul (1981). "On Not Learning From One's Own Mistakes", Communication Research, 8(1): 3-37.

Morgan, Michael (1984). "Heavy Television Viewing and Perceived Quality of Life", Journalism Quarterly, 61: 499-504..

Morgan, Michael (1995). "The Critical Contribution of George Gerbner", içinde A Different Road of Taken, Ed. John A. Lent, WestviewPress: 99-117.

Morgan, Michael ve Nancy Signorielli (1990). "Cultivation Analysis: Conceptualization and Methodology", içinde Cultivation Analysis: New Directions in Media Effects Research, Ed. Nancy Signorielli ve Michael Morgan, Sage Publication: 13-34.

Morgan, Michael ve James Shanahan (1997). "Two Decades of Cultivation Research: An Appraisal and Meta-Analysis", Communication Yearbook, 20: 1-45.

Özer, Ömer (2004). Yetiştirme Kuramı: Televizyonun Kültürel İşlevlerinin İncelenmesi, Anadolu Üniversitesi Yayınları, No: 1578.

Özer, Ömer (2005). "Yetiştirme Kuramının Eleştirel Bağlamında Değerlendirilmesi: Televizyonun Rezonans Etkisine Dair Bir Araştırma", Kültür ve İletişim, 8(1): 127-161.

Özer, Ömer (2005a). "The Cultivation Theory: A Research Regarding The Television's Cultural Role", Sunulmuş Bildiri, 3rd Communication in the Millenium: A Dialoque Between Communication Scholars.

Özer, Ömer (2005b). "Yetiştirme Kuramı: Televizyonla Yaşamanın İdeolojik Kültürel Sonuçlarına Yönelik Yapılan Araştırma" Anadolu Üniversitesi Sosyal Bilimler Dergisi, 5(1): 75-108.

Özer, Ömer (2005c). "Televizyonun Şiddet Özelinde Bilinç Altına Yaptığı Etkiye Yönelik Y Yetiştirme Kuramı Çerçevesinde Yapılan Araştırma", Poster Sunumu, Marmara Üniversitesi Ïletişim Fakültesi 1. Medya Okuryazarlı̆̆ı Sempozyumu.

Potter, W. James (1986). "Perceived Reality and the Cultivation Hypothesis", Journal of Broadcasting and Electronic Media, 30(2): 15974.

Potter, W. James (1991). "Examining Cultivation From a Psychological Perspective Component Subprocesses", Communication Research, 18(1): 77-102.

Potter, W. James (1991a). "The Linearity Assumption in Cultivation Research", Human Communication Research, 17(4): 562-83.

Potter, W. James (1991b). "The relationships Between First -and Second- Order Measures of Cultivation", Human Communication Research, 18(1): 92-113.

Rubin, M. Alan vd. (1988). "A Methodological Examination of Cultivation", Communication Research, 15(2): 107- 34.

Shanahan, James ve Michael Morgan (1999). Television and its Viewers Cultivation Theory and Reseearch, Cambridge University Press.

Taylan, H. Hasan (2011). Televizyonla Yetişmek Televizyon şiddetinin etkileri üzerine bir araştırma, Çizgi Kitabevi.

Yumlu, Konca (1987). Kitle Kültürü Oluşumunda Televizyonun Rolü, Dokuz Eylül Üniversitesi Sosyal Bilimler Enstitüsü: Yayımlanmamış Doktora Tezi. 